\title{
Giant Pericardial Cyst with Thymic and Pancreatic Tissue
}

\author{
Crailsheim Ingo ${ }^{1 *}$, Krenbek Dagmar ${ }^{1}$, Bonatti Johannes ${ }^{1}$, Winkler Bernhard ${ }^{1}$ and Grabenwöger \\ Martin $^{1,2}$ \\ ${ }^{1}$ Department of Cardiac and Vascular Surgery, Vienna North Hospital and Karl Landsteiner Institute of Cardiovascular Surgical \\ Research, Austria \\ ${ }^{2}$ Sigmund Freud University, Medical Faculty, Vienna, Austria
}

*Corresponding author: Ingo Crailsheim, Department of Cardiac and Vascular Surgery, Vienna North Hospital and Karl Landsteiner Institute of Cardiovascular Surgical Research, Austria

\begin{tabular}{|c|c|}
\hline ARTICLE INFO & ABSTRACT \\
\hline Received: November 06, 2020 & We present a 33-year-old woman suffering from recurrent bronchitis, dyspnoea and \\
\hline Published: November 18, 2020 & $\begin{array}{l}\text { breast pain. Her past medical history was normal. In the trans-thoracic echocardiogram, } \\
\text { no abnormality could have been detected. However, chest X-ray and MRI showed a 9x7 }\end{array}$ \\
\hline \multirow[t]{2}{*}{$\begin{array}{l}\text { Citation: Crailsheim Ingo, Krenbek Dag- } \\
\text { mar, Bonatti Johannes, Winkler Bernhard, } \\
\text { Grabenwöger Martin. Giant Pericardial } \\
\text { Cyst with Thymic and Pancreatic Tis- } \\
\text { sue. Biomed J Sci \& Tech Res 32(1)-2020. } \\
\text { BJSTR. MS.ID.005181. }\end{array}$} & $\begin{array}{l}\text { the cyst could be removed without opening the pericardium. The patient was discharged } \\
\text { on the eighth day after surgery. The pathology-report did not confirm the preoperative } \\
\text { diagnosis of a pericardial cyst, but showed thymic and pancreatic tissue, suspicious } \\
\text { for a mature teratoma. Giant cysts in this location are rare. A literature review will be } \\
\text { presented in addition to the current case report. }\end{array}$ \\
\hline & $\begin{array}{l}\text { Keywords: Giant Pericardial Cyst; Cyst with Pancreatic Tissue; Cyst Heart; Mediastinal } \\
\text { Cyst }\end{array}$ \\
\hline
\end{tabular}

\section{Introduction}

In this case report, we introduce a young patient suffering from a giant benign mediastinal cyst, suspicious for a pericardial origin. The patient had rather typical symptoms such as dyspnoea, recurrent bronchitis and non-regular breast pain. Other less frequent symptoms like haemoptysis, pneumothorax and were not observed. Pericardial cysts are rare especially of this size. The estimated incidence is 1:100 000 . Their diameter is usually between $1-5 \mathrm{~cm}[1,2]$. In over $2 / 3$ of the cases pericardial cysts are found in the right cardio phrenic angle [2]. They are mostly incidentally found and often without any symptoms at all, although in few cases compression related symptoms have been observed. Pericardial cyst calcification or rupture occur rarely [3]. We carried out a literature review which revealed 18 cases listed from 2000 to 2020 in PubMed (Table 1). In the following text, we will discuss the different kind of performed examinations, therapy options and histology. No difference in the incidence between males and females has been reported (4). Other cysts in the mediastinum are bronchogenic (34\%), enteric (12\%), thymic and others $(21 \%)[4,5]$.

\section{Case Presentation}

A 33 year old female, turkish patient presented herself with unregular episodes of bronchitis, last time 3 months ago, and episodes of breast pain. A CT and MRI performed at time of first contact showed a 9x7 cm measuring, cyst located at the right-sided pericardium and mediastinum. Also, cysts in kidneys and liver were described. We performed a chest X-ray which also showed the tumour. The apical four chamber view of the trans-thoracic echocardiography showed, normal left and right ventricular function and size and a bicuspid aortic valve but otherwise no signs of a valvar disease. No tumour could be in this examination. The ECG showed a normal SR. The lab tests revealed a slight elevation of CRP (21.4 mg/l) but a normal white cell count (7.7 G./l). Tumour markers were negative, but antibodies for hepatitis A were detected. The urinary status showed a fungus caused, urogenital infection (Figure 1). During the operation a full sternotomy was performed and we managed to expose/develop the cyst in toto without opening the pericardium. A cranial stem was ligated and the cyst was cut off. 
During ex situ incision brown fluid was evacuated from the cyst. The patient could be transferred to the regular ward after one night at the ICU and was mobilized in a stepwise manner. On the third postoperative day we observed increasing pleural effusion on the right side and an additional chest tube was inserted. No further postoperative events occurred and the patient was discharged on the $8^{\text {th }}$ postoperative day (Figure 2).

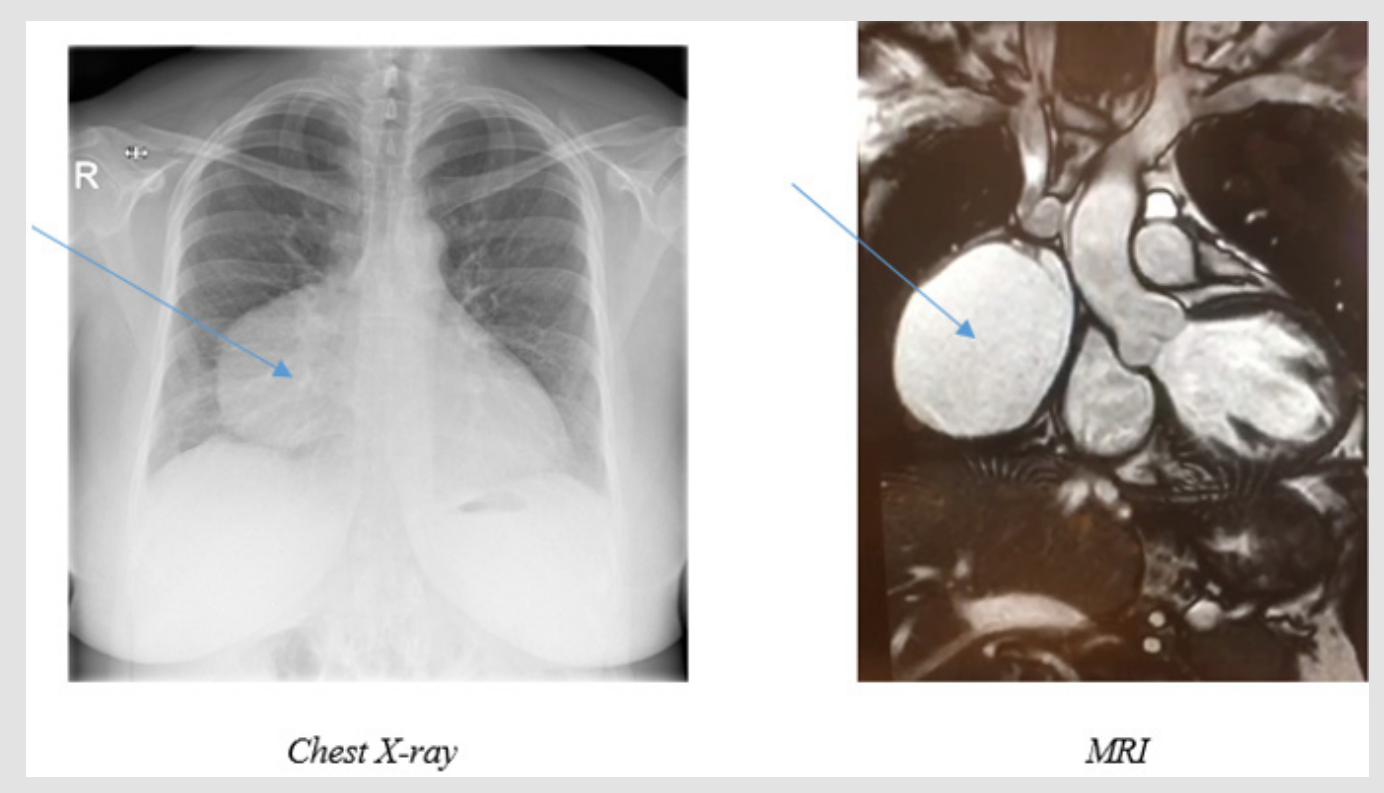

Figure 1.
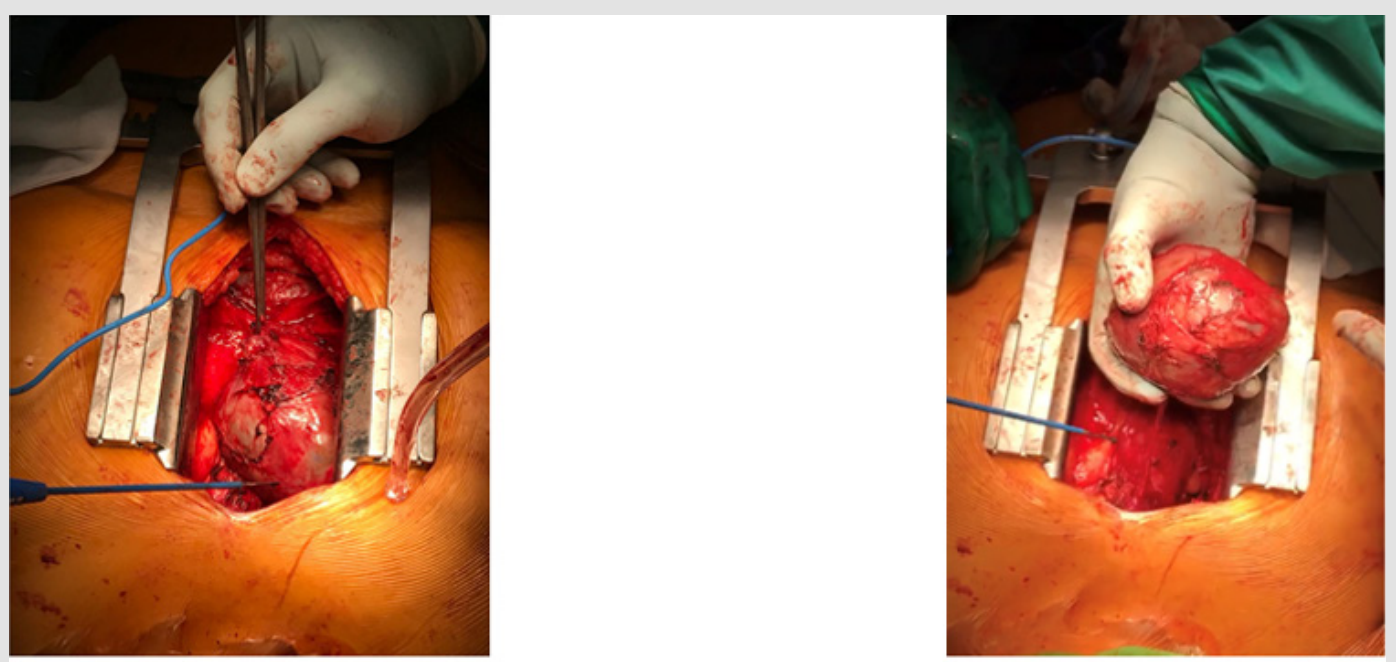

\section{Perioperative pictures}

Figure 2.

The pathology report described macroscopically a 9:7 cm cyst with a $5 \mathrm{~cm}$ long stem. It showed a chambered configuration, the biggest chamber measured of $7 \mathrm{~cm}$. The calibre of the wall varied between 3 and $8 \mathrm{~mm}$. Microscopically, the inner wall of the cyst consisted mainly of high-prismatic ciliated epithelia with some goblet cells. Furthermore, some inflammatory cells could were observed. Interestingly pancreatic tissue, with partly secretion filled excretory ducts as well as thymatic tissue was found in the cyst wall (Figure 3). The cytological examination of the cysts content showed repeating crystalline structures, with a high amount of macrophages. The following overall diagnosis was established: most likely benign mediastinal cyst with ectopic pancreatic tissue vs. a mature teratoma. 


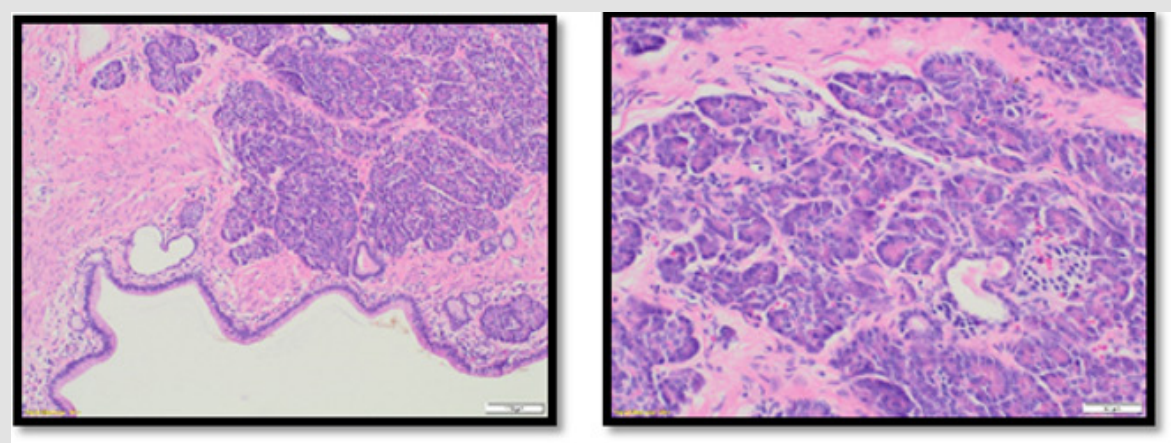

Cystic wall with Ectop, Pancreatic Tissue

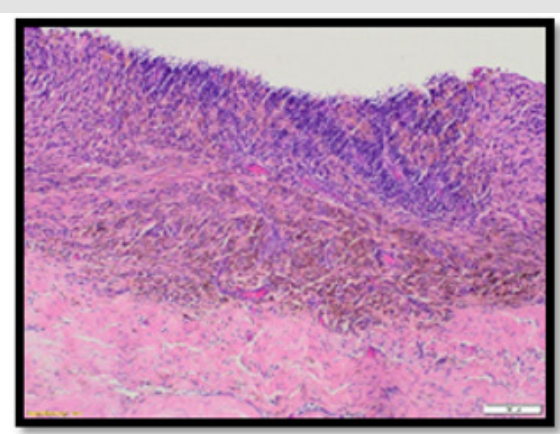

Granulation Tissue

Figure 3.

\section{Discussion}

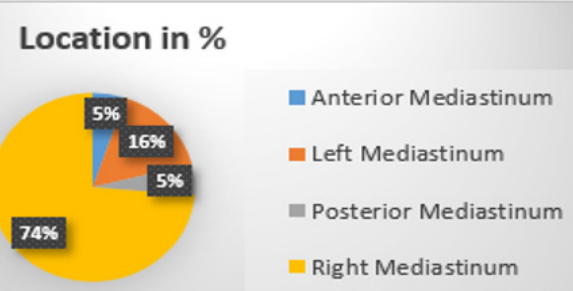

Diagram 1: Location in \%.

Pericardial cysts are rare entities and comprise $7 \%$ of all mediastinal masses. They are uncommon, benign congenital lesions found in over $60 \%$ in the middle mediastinum. These tumours occur in 1 per 100,000 people [1,2]. Pericardial cysts are most commonly smooth, unilocular cysts, mostly occurring congenitally. Their formation may result from failure of fusion of one of the mesenchymal lacunae that form the pericardial sac $[3,5]$. However, pericarditis, bacterial or parasitic infection, previous cardiac surgery or thoracic trauma, may also result in occurrence of pericardial cysts [6]. Reported cases show diameters between $2-28 \mathrm{~cm}$, however mostly under $3 \mathrm{~cm}[5,7]$. These cysts are usually detected in individuals in their third or fourth decade of life and there is no difference in the incidence of pericardial cysts between males and females $[6,8,9]$. In literature, only 20 cases of pericardial cysts in patients under 18 years have so far been described [4]. The differential diagnosis also has to include other mediastinal cysts such as bronchogenic (the most common), followed by enteric, thymic and others (including teratomas) [2,5]. Pericardial cysts are mostly found incidentally, most commonly on chest X-ray $(50 \%$ $75 \%$ ] [10]. Potential complications of pericardial cysts, including compression of the heart, syncope, cardiac tamponade, bronchial compression, and sudden death are rare [11-14]. Diagnostic methods include trans-thoracic echocardiography, CT scan and Magnetic Resonance Imaging (MRI). It has to be considered, however, that like in our case, also in echocardiography a cyst might not be detected. On CT scan, the pericardial cyst is usually a thinwalled, sharply defined, oval homogeneous mass. Its attenuation is slightly higher than water density (30-40 HU). However, no studies have shown the superiority of contrast CT over MRI and echocardiography for diagnosis or follow-up [10,15] (Diagram 1).

Without histology a final diagnosis is not possible. On histologic examination, pericardial cysts are normally composed of fibrous tissue lined by mesothelium, like normal pericardium, with mild chronic inflammation [6]. Interestingly, our cyst presented thymic tissue, especially in the stem like in a thymatic cyst and also pancreatic cells. Those, rather uncommon different epithelial structures suspected a mature cystic teratoma and not a pericardial cyst. The management of pericardial cysts depends on their symptoms. The treatment options for pericardial cysts include either observation with regular echocardiographic controls for patients without symptoms or increasing cyst size. The frequency of follow up imaging has not been standardized yet [15]. Contrastenhanced CT scan has been the modality of choice for diagnosis and follow-up [16]. Percutaneous aspiration and/or drainage and surgical resection are the methods of choice for symptomatic patients or patients with large asymptomatic cysts given that they are associated with an increased risk of complications. [17] But high recurrence rates up to $30 \%$ have been reported for aspiration and percutaneous drainage $[17,18]$.

The surgical resection can by performed by thoracotomy, sternotomy or Video-Assisted Thoracic Surgery (VATS) [7,16]. Video-Assisted Thoracoscopic Surgery (VATS) is a valuable intervention for resection of pericardial cysts with lower morbidity and mortality rates than thoracotomy [17]. Percutaneous aspiration, as mentioned, is another method, but with the high recurrence rates mentioned above [16]. A non-operative strategy may be selected for high-risk patients. Also spontaneous disappearances have been observed $[19,20]$. Surgery is the only definitive curative treatment has been demonstrated as up to date [2]. 


\section{Pancreatic Tissue In Giant Mediastinal Cysts}

Pancreatic tissue in the anterior mediastinum was first described pathologically by Klob, et al. [20,21] It is mostly found in adolescents and adults, with an avarage of 29 years, females are slightly more frequently affected (58\%) [20]. Generally, the occurrence of ectopic pancreatic tissue in the mediastinum is rare it is generally been more often observed in tumors of the gastrointestinal tract (70-90\%), mainly in the stomach and small intestine $[22,23]$. When found in the thorax, it is mostly a component of gastroenteric duplication cysts, teratomas or intralobular pulmonary sequestration [22,24]. Up to date, the aetiology of this anomaly is still topic of research [23,24]. However, one theory describes an abnormal differentiation of the pluripotent epithelial cells of the ventral primary foregut resulting in ectopic pancreatic tissues in the mediastinum, based on pancreas and lower respiratory tract, sharing the same embryological origin from the primitive foregut $[23,24]$. Interestingly, in some cases Hypoglycaemia has been reported [21] (Tables 1 \& 2) [3,5,25].

Table 1: Published cases of giant pericardial cysts from 2000 to 2020 [1-18].

\begin{tabular}{|c|c|c|c|c|c|c|}
\hline Reference & Publication Year & Gender & Age, $y$ & Size & Symptoms & Location \\
\hline Crailsheim et al. & 2020 & $\mathrm{~F}$ & 33 & $9 \times 7 \mathrm{~cm}$ & Bronchitis, Chest Pain & Right Mediastinum \\
\hline Gharedari et al. [1] & 2019 & M & 57 & $9 \times 9 \mathrm{~cm}$ & None & Right Mediastinum \\
\hline Amr et al. [2] & 2018 & M & 36 & $10.9 \times 7 \times 13.2 \mathrm{~cm}$ & $\begin{array}{c}\text { Hypertension, Dyspnoea, Chest } \\
\text { Pain, fever }\end{array}$ & Left Mediastinum \\
\hline Hekmat, et al. [3] & 2015 & M & 24 & $13 \times 8 \times 5 \mathrm{~cm}$ & Dyspnea and Cough & Right Mediastinum \\
\hline Simsek et al. [4] & 2014 & M & 28 & $6.4 \times 9 \mathrm{~cm}$ & Fever, Cough, Chest Pain & Right Mediastinum \\
\hline Masood et al. [5] & 2013 & $\mathrm{~F}$ & Unknown & $11 \mathrm{x} 11 \mathrm{~cm}$ & Chest Pain & Right Mediastinum \\
\hline Hamad et al. [6] & 2013 & M & 30 & $11.2 \times 7.4 \mathrm{~cm}$ & $\begin{array}{l}\text { Weight loss, Chest Pain, } \\
\text { Palpitation }\end{array}$ & Right Mediastinum \\
\hline Forouzandeh et al. [7] & 2012 & $\mathrm{~F}$ & 71 & $8 \times 5 \mathrm{~cm}$ & Dyspnea, Cough, Fever & Right Mediastinum \\
\hline Mwita et al. [8] & 2012 & M & 22 & $10 \times 5 \mathrm{~cm}$ & $\begin{array}{l}\text { Lower Limb Swelling, } \\
\text { Abdominal Distention }\end{array}$ & $\begin{array}{c}\text { Anterior } \\
\text { Mediastinum }\end{array}$ \\
\hline Sokouti et al. [9] & 2012 & M & 36 & $14 \times 10 \times 7 \mathrm{~cm}$ & Cough, Chest Pain & Right Mediastinum \\
\hline Celik et al. [10] & 2012 & M & 54 & $6.5 \times 4.7 \mathrm{~cm}$ & ACS & Left Mediastinum \\
\hline Kaklikkaya [11] & 2011 & M & 39 & $22 \times 15 \times 7 \mathrm{~cm}$ & Chest Pain & Left Mediastinum \\
\hline Kumar et al. [12] & 2011 & M & 5 & $10 \times 9.5 \times 9 \mathrm{~cm}$ & Chest Pain, Cough, Fever & Right Mediastinum \\
\hline Thanneer et al. [13] & 2011 & $\mathrm{~F}$ & 22 & $\begin{array}{l}21.5 \times 11.4 \times 14.2 \\
\mathrm{~cm}\end{array}$ & Syncope & \\
\hline Matono et al. [14] & 2010 & M & 38 & $12 \times 10 \mathrm{~cm}$ & None & Right Mediastinum \\
\hline Niezel et al. [15] & 2010 & $\mathrm{~F}$ & 59 & $5 \times 5$ & Atrial Flutter, Presyncope & $\begin{array}{c}\text { Posterior } \\
\text { Mediastinum }\end{array}$ \\
\hline Pereira et al. [16] & 2008 & $\mathrm{~F}$ & 73 & $14 \times 10 \times 7 \mathrm{~cm}$ & Chest Pain & Right Mediastinum \\
\hline Nina et al. [17] & 2007 & $\mathrm{~F}$ & 44 & $13 \times 9.5 \mathrm{~cm}$ & Dyspnea, Chest Pain, Cough & Right Mediastinum \\
\hline Demellis et al. [18] & 2001 & $\mathrm{~F}$ & 27 & $15.6 \times 12.2 \times 5.6 \mathrm{~cm}$ & None & Right Mediastinum \\
\hline
\end{tabular}

Table 2: Published cases of giant ectop pancreatic tissue in mediastinal cysts in adults until 2020 [19-32].

\begin{tabular}{|c|c|c|c|c|}
\hline Reference & Publication Year & Gender & Age, $y$ & Size \\
\hline Crailsheim et al. & 2020 & $\mathrm{~F}$ & 33 & $9 \times 7 \mathrm{~cm}$ \\
\hline Snak et al. [19] & 2018 & $\mathrm{~F}$ & 21 & $7.6 \times 7.5 \mathrm{~cm}$ \\
\hline Li et al. [20] & 2014 & M & 18 & $16 \times 12 \times 9 \mathrm{~cm}$ \\
\hline St Romain et al. [21] & 2012 & $\mathrm{~F}$ & 66 & $11 \times 9 \mathrm{~cm}$ \\
\hline Byun et al. [22] & 2012 & $\mathrm{~F}$ & 31 & $4 \times 3 \times 4 \mathrm{~cm}$ \\
\hline Fayoumi et al. [23] & 2010 & M & 51 & $10 \times 7 \times 5 \mathrm{~cm}$ \\
\hline Fayoumi et al. [23] & 2010 & M & 42 & $10 \times 5 \mathrm{~cm}$ \\
\hline Ehricht et al. [24] & 2009 & M & 25 & $15 \times 15 \mathrm{~cm}$ \\
\hline Chen et al. [25] & 2009 & $\mathrm{~F}$ & 32 & $13 \times 16 \times 8 \mathrm{~cm}$ \\
\hline Wang et al. [26] & 2007 & $\mathrm{~F}$ & 24 & $10 \times 8 \times 4 \mathrm{~cm}$ \\
\hline Al-Salam et al. [27] & 2006 & M & 40 & $8 \times 6 \times 6 \mathrm{~cm}$ \\
\hline
\end{tabular}




\begin{tabular}{|c|c|c|c|c|}
\hline Tamura et al. [28] & 2005 & M & 39 & $11 \times 8 \mathrm{~cm}$ \\
\hline Cagirici et al. [29] & 2001 & F & 45 & $10 \times 8 \mathrm{~cm}$ \\
\hline Wu et al. [30] & 1998 & F & 60 & $10 \times 15 \mathrm{~cm}$ \\
\hline Gong et al. [31] & 1997 & F & 26 & $20 \times 15 \mathrm{~cm}$ \\
\hline Carr et al. [32] & 1997 & F & 57 & $10 \mathrm{~cm}$ \\
\hline
\end{tabular}

\section{References}

1. Hynes J K, Tajik A J, Osborn M J, Orszulak T A, Seward J B (1983) Twodimensional echocardiographic diagnosis of pericardial cyst. Mayo Clinic Proceedings 58(1): 60-63.

2. Seo G W, Seol S, Jeong H, Min Gyo Seo, Pil Sang, et al. (2014) A large pericardial cyst compressing the left atrium presenting as a pericardiopleural efussion. Heart, Lung and Circulation 23(12): e273e275.

3. Mohammad H, Saman A, Arjang K, Farzad Ebrahimi (2019) Anesthetic Management of a Patient with a Giant Pericardial Cyst Compressing the Right Atrium. Case Rep Anesthesiol 2320879.

4. Christopher Komanapalli, Paul Schipper, Mithran Sukumar (2014) Pericardial Cyst. CTS Net.

5. Islas F, de Agustin JA, Gomez de Diego JJ, Olmos C Ferrera C, Luaces M, et al. (2016) Giant pericardial cyst compressing the heart. J Am Coll Cardiol 62(10): e21921.

6. Allen P, Burke FT (2010) Practical Cardiovascular Pathology. Lippincott Williams \& Wilkins.

7. Cohn LH (2012) Cardiac Surgery in the Adult.

8. Kar S K, Ganguly T, Dasgupta S, Mitra M, Bhattacharya R (2015) Pericardial cyst: a review of historical perspective and current concept of diagnosis and management. Interventional Cardiology Journal 1(1).

9. Siti Salwa M S, Anas R, Nor Hidayah A B (2013) Pericardial cyst: A rare cause of pericardial effusion. Medical Journal of Malaysia 68(1): 79-80.

10. Demos TC, Budorick NE, Posniak HV (1989) Benign Mediastinal Cysts. J Comput Assist Tomo 13(1): 132-133.

11. Bandeira F, Desa V, Moriguti J, Oswaldo, Jose A, et al. (1996) Cardiac tamponade: An unusual complication of pericardial cyst. Journal of the American Society of Echocardiography. 9(1): 108-112.

12. Martins I M, Fernandes J M, Gelape C L, Braulio R, Silva Vde C, et al. (2011) A large pericardial cyst presenting with compression of the right-side cardiac chambers. Revista Brasileira de Cirurgia Cardiovascular 26(3): 504-507.

13. Davis W C, German J D, Johnson N J (1961) Pericardial diverticulum causing pulmonary obstruction. Archives of Surgery 82(2): 285-289.

14. Fredman C S, Parsons S R, Aquino T I, Hamilton W P (1994) Sudden death after a stress test in a patient with a large pericardial cyst. American Heart Journal 127(4): 946-950.

15. Frisoli T, Grosu H, Paul S, Eden E (2011) Recurrent Rupture of a Pericardial Cyst Presenting as Syncope, Pleuropericarditis, and Pneumonitis. Chest J 140(4): 90A.

16. Najib MQ, Chaliki HP, Raizada A, Ganji JL, Panse PM, et al. (2011) Symptomatic pericardial cyst: a case series. Eur J Echocardiogr 12(11): E43.

17. Makar M, Makar G, Yousef K (2018) Large pericardial cyst presenting as acute cough: a rare case report. Case Reports in Cardiology.

18. Mohsen S, Monireh H, Samad E (2012) Pericardial Cyst Presented as Chronic Cough: A Rare Case Report Tanaffos 11(4): 60-62.

19. Angelo P, Luca P, Domenico L, Paola Milillo (2018) Spontaneous Disappearance of a Pericardial Cyst: Case Report and Literature Review. Korean J Thorac Cardiovasc Surg 51(1): 72-75.
20. Njem J, Ugwu B, Collins J, Innocent Emmanuel, Ojile Akpa Philip, et al. (2019) Aberrant pancreatic tissue in a giant mediastinal cyst: an uncommon entity J Cardiothorac Surg 14: 134.

21. Yamato T, Makoto T, Keiji K, Shigeki Taniguchi (2005) Ectopic pancreas in the anterior mediastinum. J Thorac and Cardiovasc surg 53(9): 498501

22. Sandor S, Laszlo L, Tamas T, Edit Várady, Zsófia Verzár (2012) Ectopic pancreatic tissue appearing in a mediastinal cyst. J Cardiothorac Surg $7: 22$.

23. Meha M, Nidhi M, Sonam M, Nidhi M (2017) Aberrant Pancreatic Tissue in a Mediastinal Duplication Cyst. A Rarity with Literature Review. Case Reports in Gastrointestinal Medicine. 7294896 (4).

24. Hyun MK, Jee WC, Sun YJ, Chang Lim Hyun, Young Sill Kim, et al. (2015) Ectopic pancreas presenting as a solid mediastinal mas. Int J Surg Pathol 23(7): 585-588.

25. Lizhi Z, Li-Qing P, Jian-Qun Y, Hong-Mei Yuan, Zhi-Gang Chu, et al. (2014) Ectopic pancreas in the anterior mediastinum: A report of two cases and review of the literature. Oncol Lett 7(4):1053-1056.

Table 1 References

1. Gharedaghi M, Ahmadi S, Khorasani A (2019) Anesthetic Management of a Patient with a Giant Pericardial Cyst Compressing the Right Atrium, Case Rep Anesthesiol 2019: 2320879.

2. Amr B, Dalia T, Simmons A (2018) Acute Cardiac Tamponade Secondary to Ruptured Pericardial Cyst: Case Report and Literature Review. J Cardiol Cases 18(2): 43-46.

3. Hekmat M, Ghaderi H, Tatariet H, Abbas Arjmand Shabestari, Seyedeh Adeleh Mirjafari (2016) Giant Pericardial Cyst: A Case Report and Review of Literature. Iran J Radiol 13(1): e21921.

4. Simsek H, Gunes Y, Akil MA, Bilsel T (2014) Asymptomatic giant pericardial cyst mimicking dextrocardia on chest X-ray. Herz 39(8): 1013-1015.

5. Masood A, Ali O, Sequeira R (2013) A hiding in the lining: painful pericardial cyst. BMJ Case Rep.

6. Hamad HM, Galrinho A, Abreu J, Valente B, Bakero L (2013) Ferreira RC. Giant pericardial cyst mimicking dextrocardia on chest X-ray. Rev Port Cardiol 32(1): 49-52.

7. Forouzandeh F, Krim SR, Bhatt R, Abboud LN, Ramchandani M, et al. (2012) Giant pericardial cyst presenting as pneumonia. Tex Heart Inst J 39(2): 296-297.

8. Mwita J, Chipeta P, Mutagaywa R, Belson Rugwizangoga, Elijah Ussiri (2012) Pericardial Cyst with Right Ventricular Compression. Pan Afr Med J 12: 60.

9. Sokouti M, Halimi M, Golzari S (2012) Pericardial Cyst Presented as Chronic Cough: A Rare Case Report, Tanaffos 11(4): 60-62.

10. Celik T, Firtina S, Bugan B, Sahin MA, Ors F, et al. (2012) A giant pericardial cyst in an unusual localization. Cardiol J 19(3): 317-319.

11. Kaklikkaya (2011) A Giant Pericardial Cyst. Cardiovasc J Afr 22(6): e1-3.

12. Kumar S, Jain P, Sen R, Rattan K, Agarwal R, et al. (2011) Giant pericardial cyst in a 5-year-old child: A rare anomaly. Ann Pediatr Cardiol 4(1): 6870 .

13. Thanneer L, Saric M, Perk G, Mason D, Kronzon I (2011) A giant pericardial cyst. J Am Coll Cardiol. 57(17): 1784. 
14. Matono R, Shoji F, Yano T, Maehara Y (2010) Surgical resection of a giant pericardial cyst showing a rapidly growing feature. Interact Cardiovasc Thorac Surg 10(6): 1056-1058.

15. Neizel M, Kruger S, Spillner J, Kelm M, Kuhl HP (2010) A giant pericardial cyst as unusual cause for atrial flutter. J Am Coll Cardiol 55(11): 1160

16. Pereira A, Tavares NJ, Thomas B (2008) Magnetic resonance imaging of a giant pericardial cyst. Rev Port Cardiol 27(4): 547-548.

17. Nina VJ, Manzano NC, Mendes VG, Salgado Filho N (2007) Giant pericardial cyst: case report. Rev Bras Cir Cardiovasc 22(3): 349-351.

18. Dernellis J, Theodosiou P, Fois L (2001) An asymptomatic giant pericardial cyst. Int J Cardiol 2(78): 185-187.

Table 2 References

19. Snak Y, Dwianingsih E, Sumpono A, Rovi Panji, Afif Rahman (2018) Mediastinal Ectopic Pancreas with Abundant Endocrine Cells Coexisting with Mediastinal Cyst and Thymic Hyperplasia. Case Rep Pathol.

20. Li W, van Boven W, Jurhill R, Bonta P, Jouke T Annema, et al. (2014) Ectopic pancreas in a giant mediastinal cyst. The clinical respiratory journal 1: 125-128.

21. St Romain P, Muehlebach G, Damjanov I, Fan F (2012) Adenocarcinoma arising in an ectopic mediastinal pancreas. Annals of Diagnostic Pathology 16(6): 494-497.

22. Byun C S, Park I K, Kim H, Yu W (2012) Ectopic pancreas with hemorrhagic cystic change in the anterior mediastinum. The Korean Journal of Thoracic and Cardiovascular Surgery 45(2): 131-133.

23. Fayoumi S, Al Husseini L, Jalil R, Abbasi S (2010) Ectopic pancreatic tissue in the thoracic cavity: Report of two cases. The Annals of Thoracic Surgery 90(2): e25-e27.

ISSN: 2574-1241

DOI: $10.26717 /$ BJSTR.2020.32.005181

Crailsheim Ingo. Biomed J Sci \& Tech Res

(C) This work is licensed under Creative

Submission Link: https://biomedres.us/submit-manuscript.php
24. Ehricht A, Pützschler F, Weissmann K, Klenske M (2009) Ectopic pancreatic tissue within a mediastinal cyst - A rare clinical manifestation. Zentralbl Chir 134(2): 178-181.

25. Chen Z H, Yu R S, Dong F, Wang X J (2009) CT findings of an ectopic pancreas in the anterior mediastinum. Korean Journal of Radiology $10(5): 527-530$

26. Wang W, Li K, Qin W, Sun H, Zhao C (2007) Ectopic pancreas in mediastinum: Report of 2 cases and review of the literature. Journal of Thoracic Imaging 22(3): 256-258.

27. Al Salam S, Al Ashari M (2006) Ectopic pancreatic tissue in the anterior mediastinum. Virchows Arch 448(5): 661-663.

28. Tamura Y, Takahama M, Kushibe K, Taniguchi S (2005) Ectopic pancreas in the anterior mediastinum. The Japanese Journal of Thoracic and Cardiovascular Surger 53(9): 498-501.

29. Cagirici U, Ozbaran M, Veral A, Posacioglu H (2001) Ectopic mediastinal pancreas. European Journal of Cardio-Thoracic Surgery 19(4): 514-515.

30. Wu J, Chen Y (1998) Ectopic pancreas in anterior mediastinal with pseudocyst: one case report. Chinese Journal of Clinical Thoracic and Cardiovascular Surgery 14: 214.

31. Gong N (1997) Ectopic pancreas in within thorax: two case reports. Chin J Thorac Cardiovasc Surg 308.

32. Carr M J T, Deiraniya A K, Judd P A (1977) Mediastinal cyst containing mural pancreatic tissue. Thorax 32(4): 512-516.

$\begin{array}{ll}\text { BIOMEDICAL } & \text { Assets of Publishing with us } \\ \text { RESEARCHES } & \text { - Global archiving of articles } \\ & \text { - Immediate, unrestricted online access } \\ & \text { - Rigorous Peer Review Process } \\ & \end{array}$

